\title{
Leiomyomatosis peritonealis disseminata with endometriosis
}

\author{
Bo Ram Yu (1) , ${ }^{1}$ Sun Young Lee, ${ }^{2}$ Dong Hyu Cho (1) ${ }^{3}$
}

${ }^{1}$ Department of Obstetrics and Gynecology, Jeonbuk National University Hospital, Jeonju, The Republic of Korea

${ }^{2}$ Department of Radiation Oncology, Jeonbuk National University Medical School, Research Institute of Clinical Medicine of Jeonbuk National University-Biomedical Research Institute, Jeonbuk National Uinversity Hospital, Jeonju, Jeollabuk-do, The Republic of Korea

${ }^{3}$ Department of Obstetrics and Gynecology, Jeonbuk National University Medical School, Research Institute of Clincal Medicine of Jeonbuk National University-Biomedical Research Institute, Jeonbuk National University Hospital, Jeonju, The Republic of Korea

\section{Correspondence to} Professor Dong Hyu Cho; obgyn2001@jbnu.ac.kr

Accepted 19 June 2021

\section{DESCRIPTION}

A 49-year-old female patient was transferred to our hospital due to suspicion of severe adhesion and malignant tumours during surgery at a local hospital with an adnexal tumour a week ago. There was no history of gynaecological surgery before this surgery.

On pelvic examination, a solid, fixed mass as large as small fist was palpated in the left adnexal region of the uterus. Her body mass index was 25.6 $\mathrm{kg} / \mathrm{m}^{2}$. As routine, her full blood counts and serum biochemistry were within the normal ranges. The serum cancer antigen 125 level was elevated (44.0 $\mathrm{U} / \mathrm{mL}$ ).

Transvaginal ultrasonography revealed a solid mass measuring $4.3 \times 5$ within the left adnexa. Contrast-enhanced CT images of the abdomen and pelvis showed a $6.5 \times 5 \mathrm{~cm}$ sized mass with heterogeneous enhancement within the left adnexa and multiple nodular lesions in the pelvic cavity (figure 1).

It was presumed to be a malignant ovarian tumour and exploratory laparotomy was performed. The left adnexal mass observed on ultrasound was determined to be a hard, round ovarian mass that was adhered to the left fallopian tube and the mesentery of the sigmoid colon. Right adnexa had a grossly normal appearance. Innumerable small nodules were present in the mesentery, the omentum, uterus and the serosal surface of the sigmoid colon (figure 2). Intraoperative frozen section analysis suggested a benign mesenchymal tumour. She underwent total hysterectomy, left unilateral salpingo-oophorectomy and sigmoid colectomy with optimal resection of the disseminated nodules.

Histopathological examination of the resected nodules revealed them to be less than $1 \times 3 \mathrm{~mm}$ in the peritoneum and $19 \times 17 \times 12 \mathrm{~mm}$ in the omentum. These nodules were composed of smooth muscle cells arranged in fascicles. In addition, this nodule included haemorrhaging endometrial tissue
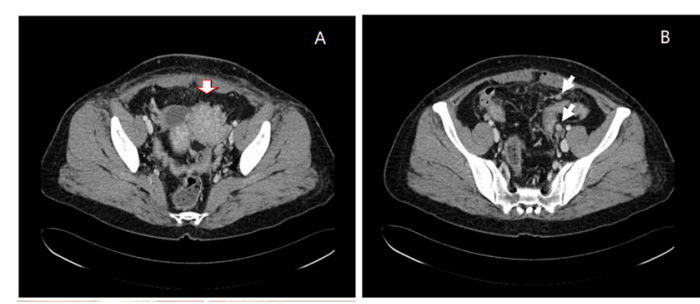

Figure 1 Contrast-enhanced CT of the abdomen and pelvis shows a mass with heterogeneous enhancement at the left ovary and multiple areas of pelvic nodularity suspicious of pelvic seeding (arrows).
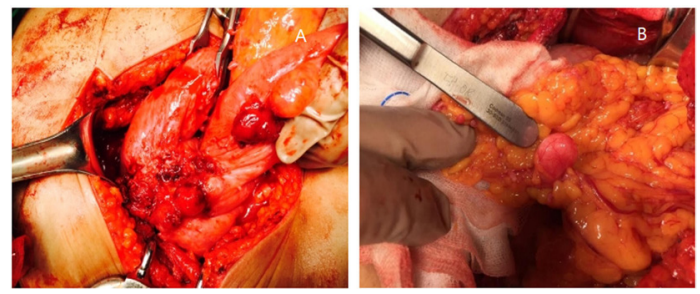

Figure 2 Intraoperative findings reveal multiple nodules with smooth surface, which are adhesive with fallopian tube, mesentery of the colon and omentum.
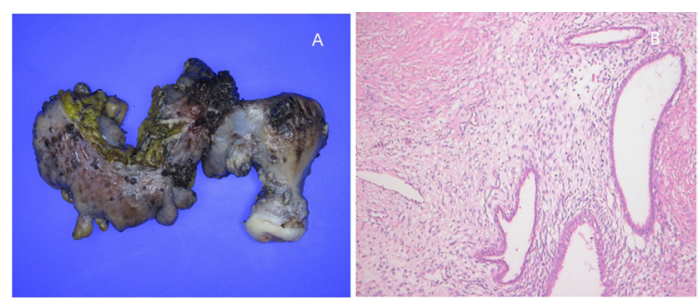

Figure 3 Histologic features $(A)$ there are multiple tiny-sized white grey nodules on the surface of the uterus, fallopian tube and sigmoid colon. (B) Endometrial gland and stromal cells without atypia, H\&E stain, $\times 200$.

with smooth muscle cells. The nodule was positive for oestrogen receptors and progesterone receptors (figure 3). According to these results, the final diagnosis was leiomyomatosis peritonealis disseminata (LPD) with endometriosis.

The patient was discharged 1 week after surgery and was treated with ulipristal acetate for 3 months. During the follow-up for 5 years, she is doing well without recurrence.

LPD is a rare, benign disease in premenopausal and postmenopausal women. Although the mechanism of LPD has still not been established, high estrogenic status is considered as a causative factor. Reproductive age, prolonged use of oral contraceptives, hormonal replacement therapy and estrogensecreting tumour may induce LPD according to several case reports. ${ }^{1} 2$ Similarly, endometriosis is one of the well-known estrogen-dependent diseases, and several cases of LPD with endometriosis have been reported. ${ }^{3}$ One possibility is that it might be connected to a 'Müllerianosis condition.' Leiomyomatous nodules might be derived from the Müllerian epithelium. Smooth muscle might be contained sufficiently below the peritoneum in the pelvic cavity. ${ }^{4} \mathrm{~A}$ high serum oestrogen level may stimulate the proliferation of Müllerian derivatives to LPD. In our case, the ovarian malignant tumour was the presumptive diagnosis and the oestrogen 
level was not evaluated before the operation. However, it is most likely caused by an increase in oestrogen.

With the absence of a consensus regarding the treatment of LPD, we can only speculate on possible treatment options for LPD. A surgical approach should be considered to confirm the diagnosis. Lowering the serum estrogen level might be the primary postoperative treatment in addition to radical resection. Aromatase inhibitors or gonadotropin-releasing hormone agonists have also been proposed by several reports. ${ }^{5}$

\section{Learning points}

- 'Müllerianosis' may explain leiomyomatosis peritonealis disseminata mixed with endometriosis in the peritoneal cavity.

- Lowering the serum estrogen level might be the primary postoperative treatment in addition to radical resection.

Contributors BRY, SYL, DHC: Designed and performed experiments, the acquisition of data and co-wrote the paper. SYL: Designed the conception of the study and cowrote the paper. DHC: Designed and performed experiments, supervised the research and co-wrote the paper.
Funding The authors have not declared a specific grant for this research from any funding agency in the public, commercial or not-for-profit sectors.

Competing interests None declared.

Patient consent for publication Obtained.

Provenance and peer review Not commissioned; externally peer reviewed.

\section{ORCID iDs}

Bo Ram Yu http://orcid.org/0000-0001-7558-5363

Dong Hyu Cho http://orcid.org/0000-0002-1557-9575

\section{REFERENCES}

1 Drake A, Dhundee J, Buckley CH, et al. Disseminated leiomyomatosis peritonealis in association with oestrogen secreting ovarian fibrothecoma. BJOG 2001;108:661-4.

2 Heinig J, Neff A, Cirkel U, et al. Recurrent leiomyomatosis peritonealis disseminata after hysterectomy and bilateral salpingo-oophorectomy during combined hormone replacement therapy. Eur J Obstet Gynecol Reprod Biol 2003;111:216-8.

3 Carvalho FM, Carvalho JP, Pereira RMA. Leiomyomatosis peritonealis disseminata associated with endometriosis and multiple uterus-like mass: report of two cases. Clinical Medicine Insights: Case Reports, 2012.

4 Fredericks S, Russell P, Cooper M, et al. Smooth muscle in the female pelvic peritoneum: a clinicopathological analysis of 31 women. Pathology 2005;37:14-21.

5 Takeda T, Masuhara K, Kamiura S. Successful management of a leiomyomatosis peritonealis disseminata with an aromatase inhibitor. Obstet Gynecol 2008;112:491-3.

Copyright 2021 BMJ Publishing Group. All rights reserved. For permission to reuse any of this content visit

https://www.bmj.com/company/products-services/rights-and-licensing/permissions/

BMJ Case Report Fellows may re-use this article for personal use and teaching without any further permission.

Become a Fellow of BMJ Case Reports today and you can:

- Submit as many cases as you like

- Enjoy fast sympathetic peer review and rapid publication of accepted articles

- Access all the published articles

Re-use any of the published material for personal use and teaching without further permission

Customer Service

If you have any further queries about your subscription, please contact our customer services team on +44 (0) 2071111105 or via email at support@bmj.com.

Visit casereports.bmj.com for more articles like this and to become a Fellow 